Paideusis

\title{
A Response to Thiessen's Academic Freedom in the Religious College and University (2)
}

\section{Joyce Bellous}

Volume 10, Number 1, 1996

URI: https://id.erudit.org/iderudit/1073207ar

DOI: https://doi.org/10.7202/1073207ar

See table of contents

Publisher(s)

Canadian Philosophy of Education Society

ISSN

0838-4517 (print)

1916-0348 (digital)

Explore this journal

Cite this article

Bellous, J. (1996). A Response to Thiessen's Academic Freedom in the Religious College and University (2). Paideusis, 10(1), 24-29.

https://doi.org/10.7202/1073207ar 


\section{A Response to Thiessen's Academic Freedom in the Religious College and University (2)}

\section{Joyce Bellous, McMaster Divinity College, McMaster University}

Thiessen examines the question of whether religious institutions for higher education place special limits on academic freedom. He concludes that conditions surrounding academic freedom are not of necessity different for statesupported than for religiously-based colleges. He contends that all institutions place limits on academic freedom and that academic freedom is possible in religious schools because religious commitment does not "in and of itself" negate the possibility of academic freedom (p. 12). He develops his argument by posing what he calls postmodern concerns about academic freedom and argues against the possibility of full academic freedom. I share Thiessen's disquiet about the rights and well-being of religious colleges in his important and timely critique. In response, I will pursue the question of whether he is wrestling with scarecrows or real villains?

Thiessen's intellectual opponents claim that religious colleges do put special limits on academic freedom, and they find these limits objectionable. McIver's criticism of religious institutions is strong. Thiessen points out that central documents on academic freedom in the United States imply that religious institutions place a special burden on academic freedom. Suppose we take McIver's complaint about religious colleges as representative. He proposes a connection between values that divide group from group and the destruction of the mission of the university to pursue knowledge wherever it may lead. There are three issues at stake here-namely, the freedom to pursue whatever content an academic chooses, the freedom to pursue thought where ever it may lead, and the responsibility to establish values that do not divide group from group.

On the third issue, Mclver assumes that it is possible to have values that do not divide group from group. But his assumption fails to note the effects of modernity on the constitution and maintenance of personal and social identity. Modernity overturned a pre-modern human solidarity in which personal and social identity did not show up as a problem because identity was equivalent to the place one held within a feudal family system. A characteristic practice of modernity was to divide group from group along racial, political, cultural, and linguistic lines-for example, in the constitution of the modern nation-state (see Foucault, 1970, 1979; Hobsbawn, 1991). Now, no one teaches in the absence of values that divide group from group. To assume that some one could misses the point of current social realities which stratify people along the lines of gender, language, race, politics, culture, and wealth, in addition to religion. At the end of the twentieth century, we need to teach people how to live reasonably together in the face of divisions that invade and shape our self-concepts. It is mis-educative (and unjust) to suggest these divisions do not exist. 
The two other issues in the judgement made against religious colleges are raised by Thiessen. The first he addresses by spelling out the limits on all our attempts at academic freedom. If it is conceptually impossible to have limitless academic freedom, as Thiessen insists, then Mclver claims too much when he asserts that to propagate a creed or set of values is to destroy the university. Universities come into being and continue to exist through the propagation of a set of values that are intellectual, economic, political, and cultural. The precedence placed on literacy, as opposed to orality, as well as on our cultural and technological demands for numeracy, are assertions about what matters in life, what matters less, and what does not matter at all.

The other aspect of a secular judgement against religious colleges is less easy to dodge. I refer to academic freedom as an inquiry which follows its own lead. Freedom here is conceived as the freedom to follow out an idea regardless of where it takes us. Criticisms of religious colleges imply that commitment interferes with the pursuit of an idea if the quest might bring believers to positions that are forbidden in advance by their religious institution. Thiessen is aware of the stickiness of this notion of academic freedom as the unhindered pursuit of an idea. He admits there is a difference between church-supported and state-based institutions of higher learning and he probes what he thinks about these differences. In taking the issue of difference seriously, the question arises as to whether the differences in question signal the inferiority of religious institutions as sites for higher learning. If we compare institutions and judge that one is different from the other, what may follow is the judgement that one is not as valuable as the other. Assertions by those who criticize religious colleges are of this sort: religious colleges provide an inferior climate for academic freedom because their commitments limit the free range of ideas. The dynamics between difference and value is a central concern in postmodern critiques. And I would like to push the issue of difference and value a little further in a moment.

Thiessen's solution to the problem of academic freedom in religious institutions is to have all institutions for higher learning state their typical limitations to academic freedom so that religious institutions are not singled out. By identifying all cases, we become aware of limits on academic freedom. To take this tack is to treat all institutions fairly by treating them the same. But postmodem responses treat people fairly by paying attention to their differences. In addition, it puzzles me that he includes a view from nowhere as a "heuristic principle" for thought (p. 11), though earlier he criticized the possibility of coming from nowhere. I think he was right the first time. How can we think from nowhere? Admitting limitations is not the same as believing that we can come from nowhere, even at some future point in time. In making these two moves, Thiessen does not take the role of differences seriously enough in constituting and maintaining plausible social and personal identities. He backs away from being clear about the relationship between difference and limitation. ${ }^{1}$

In order to reflect on the relationship between difference, value, and coming from nowhere, I want to identify my self. I am a feminist, Canadian, anglophone, Christian, philosopher of education living at the end of the twentieth century. I have taught at state-supported universities and now teach in a religious college. In short, I am situated, embodied, and constrained. There are two related, possible outcomes to naming my self. One is that I may be judged 
academically limited in extraordinary ways (as compared with educators in state-run universities) by teaching in a religious college. The other is that readers may assume that they know what I think, what my particular constraints are, in advance of reading further. That is, readers may feel that these labels are all they need to see in order to sum me up and stop reading. The first outcome is a result of misguided comparison; the second is a practice of neglect. None of us wants the significance of what we say to be reduced to nothing more than our particularity. In short, if there are limits on academic freedom due to religious commitments, they need to be shown rather than pre-judged. How does Mclver know that religious institutions teach in a special and dangerous way that "divides group from group?" What is his evidence? Religious college populations are often diverse politically, racially, socially, economically, and religiously. ${ }^{2}$ McIver's judgement mis-recognizes many institutions.

In terms of mis-recognition, we are all caught in the aftermath of a modern world we share with others who are not like us. It is hard work to recognize the value of people who are different from us. Mis-recognition is linked to ontological conflict in human experience. Taylor $(1979$, p. 46$)$ observes that: "Finite beings just in virtue of existing externally [facing the world bodily] in space and time make a claim to independence, while the very basis of their existence is that they express a spirit which cannot brook this independence." We hesitate to declare ourselves due to the detrimental experiences of being pre-judged (or the fear of them) by those we continue to need. The tendency to mis-recognize those who are different is a practice of oppression which Taylor identifies as a form of social harm-that is, there is a relationship between identity formation, identity maintenance, and social recognition. In discussing recognition's role in social identity, Taylor $(1992$, p. 46) insists that we "continue to care about social esteem" and can "flourish only to the extent that we are recognized. Each consciousness seeks recognition in another, and this is not a sign of a lack of virtue" (49). Our identity is partly shaped by recognition or its absence, often by the mis-recognition of others (personal and social), and we can suffer real damage, real distortion, if the society around us mirrors back to us a demeaning or contemptible picture of our selves. Recognition is not just a courtesy we owe each other. It is a vital human need (Taylor, 1992, pp. 25-26). In order to protect our selves from mis-recognition, it is easy to persuade our selves that it is prudent to come from nowhere. Rather than holding up the possibility of coming from nowhere as a heuristic, we need experiences that help us to be sure of our selves, but also that help us dialogue with those who are different and who help us see our selves more clearly in the light of these differences. This sort of dialogue can and does happen in religious colleges.

Although I agree with much of what Thiessen says, I would like clarification on one point. He sets out his thesis in the following way: religious colleges do not of necessity limit academic freedom. He then asserts that the search for truth is always guided by assumptions and preconceptions that will "of necessity function as constraints on freedom of inquiry" (p. 7). He argues that religious institutions do not of necessity limit academic freedom, any more than other institutions do by virtue of the existential constraints that apply to all human beings living in society. I would like to hear more about what he thinks about how we think. He admits it is crucial to see that assumptions and precon- 
ceptions serve not only as constraints on freedom of inquiry (p. 7) but there seems to be an inconsistency between these two assertions about necessity.

The second concern I have is his reference to postmodernity. In making his postmodern critique, Thiessen (p. 8) asserts that postmodernity uncovers the myth of an a-historical, non-contingent, rational self. Here, I agree with him. He introduces the presence of an embodied, historical and situated self as a critique of the idea of academic freedom that fails to take stock of itself in light of these existential human limitations (which is why coming from nowhere is not an option). But his analysis of post modernity gets a false start. The heart of postmodernity is not to "recapture the pre-Enlightenment respect for tradition" (p. 9). postmodernity is a radical critique of the way things are right now. It does not posit anything in a coherent or consistent way. Further, its form of critique is not new historically (for example, see Taylor, 1979, pp. 1-14).

Postmoderns assert that we are in the midst of a new flood of thought due to intellectual, socio-political, economic, and technological change. We have three options in the midst of these flood waters. We could pack up camp and move to a new location. In doing this, we assume that the history of human thought needs a new beginning and the language we currently use will not travel well with us. Or else, secondly, we might tinker with the flow of what we already know, using new language tools to make the project work. Thirdly, we might accept that revision to the mainstream of thought must be deep but that it will come from within the borders of the current flood tide and so busy our selves sorting through the flotsam and jetsam of earlier periods in order to make sense of new opportunities and spot past mis-directions that constitute a distorted picture of the human world.

In all these approaches lurks the figure of truth. Thiessen uses postmodern insights without addressing directly the problem that the modern notion of truth presents to us in the aftermath of our willingness to be imperialistic. He is aware of the problem of truth and so raises the question of relativism. In my view, the strength and usefulness of relativism is as an antidote to cultural imperialism in the last century. Relativism constitutes a necessary step in ridding our selves of the tendency to impose personal truth on others in an absolute and dogmatic way; imperialism fails to recognize that what we consider to be true may make no sense to others. Thiessen does raise the issue of perspectivism and this is important. Relativism asserts that all views are of equal value and is distinct from perspectivism, which asserts that all views are interpretations and that some interpretations are better than others (see Nehamas, 1985). Perspectivism is Nietzsche's contribution to the mainstream. His free spirits were those who let inquiry follow its own logic wherever it might lead. Yet, even they were not cavalier with their values. The point here is that authentic identity is in tension with our freedom to follow thought wherever it may lead. ${ }^{3}$ As an example, feminists are never free, implicitly or explicitly, to support the subjugation of women or the suppression of women's voices in the public sphere and still call themselves feminists. The ongoing effects of our choices build boundaries around us; our loyalties shape us (see Fletcher, 1993). In light of these constraints, if we are reasonable and take the purposive action inspired through the inner dialogue that reason encourages in us, our lives will have a trajectory that is drawn by our reflection and action. 
I agree with Thiessen's conclusion that healthy pluralism could be found in a plurality of institutions and-I would add-if they establish identity in a dialogical manner. A problem enters our inner (and social) dialogue if institutions suppress a reasonable, dialogical approach to thought and action. (Again, this must be shown not pre-judged.) And it is not only religious institutions that become monological and oppressive. The freedom to say what one thinks without suffering costly penalties is evidence of dialogical and open environments. But this is not a licence to be cavalier and careless in educational settings in which professors have so much educational power. In short, it is complex to decipher the difference between moves that constitute a reasonable, educative and growthful change in identity and those that amount to a betrayal of it. As an example, it is because Mclver believes that religious colleges betray the fundamental identity of universities that he makes his point in the first place.

People in religious institutions of higher learning feel the weight of oppressive mis-recognition in criticisms against them as an experience they share with other minorities. The oppressive force of mis-recognition from a nonreligious perspective is effective only under the condition that a religious perspective is a minority voice. Yet, Christianity itself has been monological and oppressive. The tables are turned. Human beings have a seemingly inexhaustible capacity to hurt each other in precisely the ways they have been hurt. Thiessen is wrestling with a real villain; it is the adversary of mis-recognition in all its oppressive forms.

\section{Notes}

${ }^{1}$ See Charles Taylor's (1992, pp. 25-73) analysis of the politics of equal dignity, difference, and recognition.

${ }^{2}$ My own college has students from most faith communities, including Catholic, Protestant, and Jewish people.

3 This point is investigated aphoristically by Wittgenstein who uses the metaphor of a river-bed to depict the structure that thought constitutes in all of us. He notes that we do not get our pictures of the world because they are correct; rather, they constitute the measure we use to distinguish between what is false and what is true (Wittgenstein, \#94). Further, the river-bed of our thought "consists partly of hard rock, subject to no alteration or only to an imperceptible one, partly of sand, which now in one place now in another gets washed away, or deposited" (Wittgenstein, \#99). I use this metaphor only to challenge the idea that we can easily follow thought wherever it may lead. All of us are more limited as thinking human beings than the expression intimates. See Ludwig Wittgenstein, On Certainty (Oxford: Basil Blackwell, 1979).

\section{References}

Fletcher, George P. Loyalty: An essay on the morality of relationships. Oxford: Oxford University Press, 1993.

Foucault, Michel. The Order of Things. New York: Vintage Books, 1970. - Discipline and Punish. New York: Vintage Books, 1979. 
Hobsbawn, Eric J. Nations and Nationalism Since 1780: Programme, myth, reality. Cambridge: Cambridge University Press, 1990.

Nehamas, Alexander. Nietzsche: Life as literature. Cambridge, MA: Harvard University Press, 1985.

Taylor, Charles. Hegel and Modern Society. Cambridge: Cambridge University Press, 1979.

ceton: Princeton University Press, 1992.

Multiculturalism and the Politics of Recognition. Prin-

Wittgenstein, Ludwig. On Certainty. Oxford: Basil Blackwell, 1979. 